\title{
Laparoscopic appendectomy in the elderly: our experience
}

\author{
Alessia G Ferrarese ${ }^{*}$, Valter Martino ${ }^{\dagger}$, Stefano Enrico $^{\dagger}$, Alessandro Falcone $^{\dagger}$, Silvia Catalano ${ }^{\dagger}$, Giada Pozzi $^{\dagger}$, \\ Silvia Marola ${ }^{\dagger}$, Mario Solej ${ }^{\dagger}$ \\ From 26th National Congress of the Italian Society of Geriatric Surgery \\ Naples, Italy. 19-22 June 2013
}

\begin{abstract}
Background: Laparoscopic appendectomy for acute appendicitis is one of the most common surgical procedures performed in the world. We aimed to compare laparoscopic and open appendectomy in the elderly in our experience.

Methods: We performed a retrospective review of elderly patients who underwent appendectomy for acute appendicitis from 1st of January 2006 to the 31st of July 2012. We analyzed 39 appendectomies in elderly patients: 20 procedures were performed using open technique (Group O) and 19 using laparoscopic technique (Group L).

Results: In the analysis of intraoperative variables there was no statistically significant difference. In this study there was no statistically significant difference also in peri-operative variables.
\end{abstract}

Conclusion: Laparoscopic appendectomy is a safe and feasible technique in acute appendicitis also in the elderly.

\section{Background}

Laparoscopic appendectomy for acute appendicitis is one of the most common surgical procedures performed in the world [1-3]. The first surgeon performing a laparoscopic appendectomy was Semm in UK in 1983 [4]. Acute appendicitis in the elderly is a surgical disease that could create important diagnosis problems [5-9] as far as concerns the atypical presentation [3,10-18].

We aimed to present our experience about a series of laparoscopic appendectomies in elderly patients and analyze the feasibility of laparoscopic technique in comparison with open techinique.

\section{Methods}

From the 1st of January 2006 to the 31st of July 2012 we performed 208 appendectomies in our division of General Surgery: 39 of these were performed in elderly patients (age $>65$ yrs, $30 \mathrm{M} 9 \mathrm{~F}$ ). In the elderly group, 20 procedures

\footnotetext{
* Correspondence: alessia.ferrarese@gmail.com

† Contributed equally

University of Turin, Department of Oncology, School of Medicine, Teaching Hospital "San Luigi Gonzaga", Section of General Surgery, Orbassano, Turin, Italy
}

(c) 2013 Ferrarese et al; licensee BioMed Central Ltd. This is an open access article distributed under the terms of the Creative Commons Attribution License (http://creativecommons.org/licenses/by/2.0), which permits unrestricted use, distribution, and reproduction in any medium, provided the original work is properly cited. were performed using open technique (Group O) and 19 using laparoscopic technique (Group L).

The analyzed variables were: sex, symptoms, CT or US evaluation, total hospital stay, hospital stay after and before the procedure, kind and duration of procedure, conversion to open procedure, drain and final pathological results.

Statistical proportions related to the dichotomic variables (gender distribution in the different patient groups, number of post-operative complications, conversion rate, number of drains, presence of fever, wall thickening, amount of effusion, presence of appendix perforation) were compared using Chi-square test and Fisher's exact test.

Continuous variables like age distribution, post-operative hospital stay time, surgery duration and several haematochemical characteristics (WBC, CRP) were expressed as average (range) and analyzed using the Mann-Witney $\mathrm{U}$ test. Patients distribution according to different surgical teams was confirmed. All statistical analyses were performed using $\mathrm{R}$ software (version 2.6.2), and a $p$ value of less than 0.05 was considered statistically significant.

\section{Results}

Table 1 shows demographic data of both groups.

\section{Biomed Central}


Table 1 Demographic data

\begin{tabular}{cll}
\hline & Group O & Group L \\
\hline Mean age (yrs) & 76 & 74 \\
\hline Sex M\% & 16 & 14 \\
\hline F\% & 4 & 5 \\
\hline
\end{tabular}

In the $\mathrm{O}$ group we performed a McBurney incision in 18 patients and a pararectal incision in 12 cases; all appendectomies were performed by loops. In laparoscopic appendectomy group in 11 cases we used the mechanical stapler (Table 2).

In intraoperative variables analysis there was no statistically significant difference (Table 3). In this study there was no statistically significant difference also in perioperative variables (Table 4).

Residents performed 3 surgical procedures (8,57\%), and in 17 cases the resident was in equipe as second operator, with a total resident's presence in the Surgical Team of $51,28 \%$ of cases.

The follow-up was 19 months; the only post-operative complication was a wound infection in a open appendectomy, resolved with antibiotic therapy. There was no mortality.

\section{Conclusions}

In our experience we assist to an inversion of surgical approach in acute appendicitis, with a gradual increase of laparoscopic procedures. In spite of slightly longer time of procedure, there was no significant difference in number of post-operative complications, number of drains, duration of surgical procedure and total hospital stay in laparoscopic appendectomy and open procedure [19-21]. Laparoscopic appendectomy is to be considered an advanced surgical procedure: anatomical variability and unpredictable difficulties make the procedure not standardizable.

We consider surgery approach more difficult in the elderly in some cases [22] but we also considered laparoscopic approach is, in general, a safe and feasible technique in acute pathology [23] and a safe approach also in the elderly $[24,25]$. Laparoscopic appendectomy for acute appendicitis is a gold standard technique also in the elderly.

Table 2 Surgical data (ns: not significative)

\begin{tabular}{lll}
\hline & Group O & Group L \\
\hline Mc Burney & 18 & \\
\hline Pararectal incision & 12 & \\
\hline Loops & 20 & 8 \\
\hline Stapler & & 11 \\
\hline
\end{tabular}

Table 3 Intraoperative data

\begin{tabular}{llll}
\hline & Group O & Group L & p-value \\
\hline Mean operative time (min) & 57 & 63 & ns \\
\hline Presence of perforated appendix & 2 & 3 & ns \\
\hline Abdominal effusion & 7 & 9 & ns \\
\hline
\end{tabular}

Table 4 Peri-operative data data

\begin{tabular}{llll}
\hline & Group O & Group L & p-value \\
\hline Pre-operative stay (days) & 3,2 & 3 & ns \\
\hline Post-operative stay (days) & 6,2 & 5 & ns \\
\hline Wound sepsis & 0 & 0 & ns \\
\hline Total hospital stay (days) & 10 & 8,4 & ns \\
\hline Drain apposition & 14 & 11 & ns \\
\hline Post-operative complication & 1 & 0 & ns \\
\hline
\end{tabular}

\section{Competing interests}

The authors declare that they have no competing interests.

\section{Authors' contributions}

AGF: conception and design, interpretration of data, given final approval of the version to be published.

VM: critical revision, interpretation of data, given final approval of the version to be published.

MS: acquisition of data, drafting the manuscript, given final approval of the version to be published.

AF: acquisition of data, drafting the manuscript, given final approval of the version to be published.

SC: acquisition of data, drafting the manuscript, given the final approval of the version to be published.

GP: acquisition of data, drafting the manuscript, given the final approval of the version to be published.

SM: critical revision, interpretation of data, given final approval of the version to be published

SE: conception and design, interpretration of data, given final approval of the version to be published

\section{Declarations}

Funding for this article came from personal funds.

This article has been published as part of BMC Surgery Volume 13

Supplement 2, 2013: Proceedings from the 26th National Congress of the Italian Society of Geriatric Surgery. The full contents of the supplement are available online at http://www.biomedcentral.com/bmcsurg/supplements/13/ S2

Published: 8 October 2013

\section{References}

1. Addiss DG, Shaffer N, Fowler BS, Tauxe RV: The epidemiology of appendicitis and appendectomy in the United States. Am J Epide-miol 1990, 132:910-25.

2. Temple CL, Huchcroft SA, Temple WJ: The natural history of appen-dicitis in adults: a prospective study. Ann Surg 1995, 221:278-81.

3. Gurleyik G, Gurleyik E: Age-related clinical features in older pa-tients with acute appendicitis. Eur J Emerg Med 2003, 10:200-3.

4. Semm K: Endoscopic appendectomy. Endoscopy 1983, 15:59-64.

5. Lim CY, Ree JK, Jeong YC, Chae KM: A comparative study of the appendicitis in different age groups. J Korean Surg Soc 1988, 35:207-14.

6. Hong SK, Kim HS: Clinical review of the acute appendicitis in patients over the age of 60. J Korean Surg Soc 1993, 44:449-55.

7. Sim HS, Lee YK, Hwang JY: Acute appendicitis in the aged. J Korean Surg Soc 1998, 54:695-700. 
8. An SS, Soh YS, Cho IH, Back HM, Lee SY: Clinical analysis of acute appendicitis in the elderly. J Korean Soc Coloproctol 2002, 18:274-80

9. Scher KS, Coil JA: The continuing challenge of perforating appen-dicitis. Surg Gynecol Obstet 1980, 150:535-8.

10. Owens BJ, Hamit HF: Appendicitis in the elderly. Ann Surg 1978, 187:392-6.

11. Lau WY, Fan ST, Yiu TF, Chu KW, Lee JM: Acute appendicitis in the elderly. Surg Gynecol Obstet 1985, 161:157-60.

12. Canty TG Sr, Collins D, Losasso B, Lynch F, Brown C: Laparoscop-ic appendectomy for simple and perforated appendicitis in chil-dren: the procedure of choice? J Pediatr Surg 2000, 35:1582-5.

13. Esposito C, Borzi P, Valla JS, Mekki M, Nouri A, Becmeur F, et al: Laparoscopic versus open appendectomy in children: a retrospec-tive comparative study of 2,332 cases. World J Surg 2007, 31:750-5.

14. Esposito C, Ascione G, Garipoli V, De Bernardo G, Esposito G: Complications of pediatric laparoscopic surgery. Surg Endosc 1997, 11:655-7.

15. Juricic M, Bossavy JP, Izard P, Cuq P, Vaysse P, Juskiewenski S: Laparoscopic appendicectomy: case reports of vascular injury in 2 children. Eur $J$ Pediatr Surg 1994, 4:327-8.

16. Golub R, Siddiqui F, Pohl D: Laparoscopic versus open appendec-tomy: a metaanalysis. J Am Coll Surg 1998, 186:545-53.

17. el Ghoneimi A, Valla JS, Limonne B, Valla V, Montupet $P$, Chavrier $Y$, et al: Laparoscopic appendectomy in children: report of 1,379 cases. J Pediatr Surg 1994, 29:786-9.

18. Park JB, Sul JY: Laparoscopic appendectomy: a safe primary pro-cedure for complicated appendicitis. J Korean Surg Soc 2007, 72:51-6.

19. Rispoli C, Rocco N, lannone L, Amato B: Developing guidelines in geriatric surgery: role of the grade system. BMC Geriatrics 2009, 9(SUPPL.1):A99.

20. Canty TG Sr, Collins D, Losasso B, Lynch F, Brown C: Laparoscopic appendectomy for simple and perforated appendicitis in children: the procedure of choice? I Pediatr Surg 2000, 35:1582-5.

21. Markides G, Subar D, Riyad K: Laparoscopic versus open appen-dectomy in adults with complicated appendicitis: systematic review and metaanalysis. World I Surg 2010, 34:2026-40.

22. Ferrarese A, Martino V, Falcone A, Solej M, Destefano I: Perforated duodenal diverticulum: case report and short review of the literature., su Chirurgia.

23. Solej M, Martino V, Mao P, Enrico S, Rosa R, Fornari M, Destefano I, Ferrarese AG, Gibin E, Bindi F, Falcone A, Ala U, Nano M: Early versus delayed laparoscopic cholecystectomy for acute cholecystitis. Minerva Chirurgica 2012, 67(5):381-387.

24. Ferrarese A, Martino V, Nano M: Elective and emergency laparoscopic cholecystectomy in the elderly: early or delayed approach. BMC Geriatrics 2011, 11(Suppl 1):A14.

25. Ferrarese A, Martino V, Nano M: Wound defects in the elderly: our experience. BMC Geriatrics 2011, 11(Suppl 1):A15.

doi:10.1186/1471-2482-13-S2-S22

Cite this article as: Ferrarese et al:: Laparoscopic appendectomy in the elderly: our experience. BMC Surgery 2013 13(Suppl 2):S22.

\section{Submit your next manuscript to BioMed Central and take full advantage of:}

- Convenient online submission

- Thorough peer review

- No space constraints or color figure charges

- Immediate publication on acceptance

- Inclusion in PubMed, CAS, Scopus and Google Scholar

- Research which is freely available for redistribution

Submit your manuscript at www.biomedcentral.com/submit
Ciomed Central 